\title{
Preferential attachment of Escherichia coli to different particle size fractions of an agricultural grassland soil
}

David M. Oliver ${ }^{1,2}$, Christopher D. Clegg ${ }^{1}$, A. Louise Heathwaite ${ }^{2}$ and Philip M. Haygarth ${ }^{1}$

${ }^{1}$ Institute of Grassland and Environmental Research, North Wyke Research Station,

Okehampton, Devon, EX20 2SB, UK

${ }^{2}$ Centre for Sustainable Water Management, Lancaster Environment Centre,

Lancaster University, Lancaster, LA1 4AP

Keywords: agriculture; bacterial attachment; E. coli; pollution; soil particles; sorption; water quality

Abbreviated running title: E. coli attachment to soil particles

Short communication

+Corresponding author: David M. Oliver, Centre for Sustainable Water Management, Lancaster Environment Centre, Lancaster University, Lancaster, LA1 4AP. Tel: +44 (0)1524 510231; Fax: +44 (0)1524 510217; email: d.m.oliver@lancaster.ac.uk 


\section{ABSTRACT}

This study reports on the attachment preference of a faecally derived bacterium, Escherichia coli, to soil particles of defined size fractions. In a batch sorption experiment using a clay loam soil it was found that $35 \%$ of introduced E. coli cells were associated with soil particulates $>2 \mu \mathrm{m}$ diameter. Of this $35 \%$, most of the E. coli $(14 \%)$ were found to be associated with the size fraction 15-4 $\mu \mathrm{m}$. This was attributed to the larger number of particles within this size range and its consequently greater surface area available for attachment. When results were normalised with respect to estimates of the surface area available for bacterial cell attachment to each size fraction, it was found that $E$. coli preferentially attached to those soil particles within the size range 30-16 $\mu \mathrm{m}$. For soil particles $>2 \mu \mathrm{m}$, E. coli showed at least 3.9 times more preference to associate with the 30-16 $\mu \mathrm{m}$ than any other fraction. We report that $E$. coli can associate with different soil particle size fractions in varying proportions and that this is likely to impact on the hydrological transfer of cells through soil and have clear implications for our wider understanding of the attachment dynamics of faecally derived bacteria in soils of different compositions.

\section{INTRODUCTION}

Previous research has shown that when rainfall generates runoff from agricultural land, high concentrations of faecal indicator organisms (FIOs) can be transferred from grassland to surface waters (Oliver et al., 2005a; Signor et al., 2005). However, it remains unclear whether both soil particles and FIOs are mobilised by discharge independently, or whether soil particles act as vehicles for FIO transport (Kay et al., 2007; Jamieson et al., 2005; Tyrell and Quinton, 2003). There has been much speculation that FIOs may associate with soil particles (e.g. Oliver et al., 2005b; Tyrell and Quinton, 2003; Nagels et al., 2002), and in contrast to chemical agricultural contaminants, there is a limited availability of such sorption measurements for FIOs (Kay et al., 2007; McGechan and Vinten, 2003). The dynamics of microbial association with soil particles are likely to be complex (Ling et al., 2002) and influenced by a range of factors including, for example, cell motility (McCaulou et al., 1995), 
cell type (Characklis et al., 2005), electrostatic attraction (Marshall, 1975), cell-surface hydrophobicity (Strenstrom, 1989), the presence of extracellular polysaccharides (Lunsdorf et al., 2000; Costerton et al., 1978), the presence of manure (Guber et al., 2005; Kuczynska et al., 2005) and the ionic environment within the soil / water mix and interface (Gannon et al., 1991).

A previous field experiment provided the rationale for this investigation; the patterns of emergence of $E$. coli and turbidity within a flow hydrograph followed a similar but delayed profile relative to one another (Oliver et al., 2005a, p. 924). Thus, the peaks for turbidity, flow and E. coli concentration were not identical, but occurred in respective order as a function of increasing time. The results suggested that $E$. coli may have been associated with hydrologically energised soil particles of a particular size fraction. This study was therefore designed to elucidate the attachment preference of $E$. coli with different particle size fractions. The aim of this study was to determine whether E. coli would 1) associate with soil particles, and if so, 2) would cells preferentially associate with a particular soil size fraction. It was hypothesised that $E$. coli would preferentially associate with small particle fractions because of their abundance and increased available surface area for attachment to occur.

\section{MATERIALS AND METHODS}

\subsection{Bacterial strain and culturing}

An E. coli strain originally isolated from faeces collected from cattle at the Institute of Grassland and Environmental Research (IGER), North Wyke, was used in this study. An overnight culture of E. coli in nutrient broth (Oxoid) was grown at $37^{\circ} \mathrm{C}$ and harvested by centrifugation at $2900 \mathrm{~g}$ for 30 minutes using a MSE centaur 2 centrifuge. The pelleted cells were re-suspended in sterile water and washed twice by centrifugation at $2900 \mathrm{~g}$ for 30 minutes then re-suspended once more in sterile water. The culture was then maintained at $20^{\circ} \mathrm{C}$ overnight prior to addition to soil mixes to ensure that any excess nutrients were utilized by the bacteria. 


\subsection{Soil}

Clay loam soil of the Hallsworth Series (UK Soil Survey; Harrod, 1981), a Typic Haplaquept (USDA Soil Conservation Service, 1975) was collected from ungrazed pasture (UK National Grid Reference (NGR): SX 650 995).

\subsection{The experimental approach}

A two-step batch sorption experiment was performed as illustrated in Figure 1. Step one was the crux of the experiment: briefly, treatments of soil and water and bacterial cell mixes were shaken under controlled laboratory experimental conditions to facilitate cellular contact with soil particles in a dynamic aquatic environment. Step two was a timed procedure governed by Stoke's law: soil particles were fractionated into defined size classes and the associated $E$. coli enumerated by standard microbiological plate counts. All treatments were performed in triplicate.

\subsubsection{Step one: Experimental stage}

A mass of $1 \mathrm{~g}$ (dry weight) of fresh sieved $(<2 \mathrm{~mm})$ soil was added, in triplicate, to sterile sample bottles of $25 \mathrm{ml}$ volume. To facilitate the mixing of soil with water and the addition of cells, the sample bottles were filled with $10 \mathrm{ml}$ of water collected from the River Taw at Pecketsford Bridge (National Grid reference (NGR) SX 650 950), adjacent to the plot where soil was collected, and then shaken overnight. River water was used because there was no drainage from grassland plots at the time of collection. River water was therefore the most appropriate diluent in this context. The use of an ionic dispersant may have had a chemical / ionic impact on potential cell attachment dynamics to soil particles, and was considered inappropriate for this experiment. No background counts of $E$. coli were detected in the soil and river water samples used in this study. 
The soil suspensions were then inoculated with approximately $10^{7}$ E. coli $\mathrm{ml}^{-1}$ that had been prepared as described earlier. The bottles were sealed and shaken end on end at a constant 60 rev $\min ^{-1}$ at $20^{\circ} \mathrm{C}$ for three hours (c.f. Ling et al., 2002; Gannon et al., 1991).

\subsubsection{Step two: Sedimentation stage}

The soil-cell-water suspensions from step one were transferred to graduated glass measuring cylinders and diluted to $50 \mathrm{ml}$ with river water. The purpose of the dilution was to facilitate the fractionation of the different sized particles based on their different gravity sedimentation rates.

All sedimentations were conducted at a constant temperature of $20^{\circ} \mathrm{C}$ and all samples were removed from solutions at a sampling depth of $8 \mathrm{~mm}$ (Gannon et al., 1991) at times derived from Stoke's law equation. Glass measuring cylinders were sealed with parafilm and inverted five times, end on end, to ensure thorough mixing. The cylinders were then left to allow particle sedimentation. The concentration at time $\mathrm{t}=0$ was calculated by dividing the initial inoculum concentration by the successive dilutions associated with steps one and two (on the assumption that bacterial die-off was zero during step one). Using a pipette, samples were then removed from a succession of sedimentation tubes arranged in a time series according to calculated timings (removal of sample $=T_{n}$ ). This is a method which is known to produce precise and reproducible results (Arriaga et al., 2006).

Sedimentation samples were serially diluted in sterile water and spread-plated onto MacConkey agar and incubated for $24 \mathrm{hr}$ at $37^{\circ} \mathrm{C}$ prior to enumeration of E. coli colony forming units (CFU). The difference in CFUs recorded between sample $T_{0}$ and sample $T_{n}$ was attributed to the retention and subsequent sedimentation of E. coli. Changes in E. coli population size due to die-off and / or regrowth were insignificant in the soil-water solution over the short sedimentation time period (38 minutes) (Oliver, unpublished data). One-way 
analysis of variance (ANOVA) on log transformed counts was used to test for differences between treatments.

\subsection{Determination of the attachment of $E$. coli cells to soil particles}

Using the principles embodied in Stoke's law, the specific surface area of each particle size fraction was calculated (Table 1) to approximate the number of $E$. coli cells attached per unit surface area available of each size fraction. This was done to determine if E. coli showed any preference to a particular soil size fraction. The following steps were taken:

1. Particle density; All particles were assumed to be spherical and to have the same density $\left(2.6 \mathrm{~g} \mathrm{~cm}^{-3}\right)$. These are underlying assumptions of Stoke's law upon which these experiments were based.

2. Particle volume calculation; The radius of particles was assumed to be the mid-point radius of the fraction size range.

3. Number of particles in a $1 \mathrm{ml}$ sample of each size fraction; The total mass of the fraction in $1 \mathrm{ml}$ was divided by the product of a single particle's density and volume.

4. Size range; An upper limit of $200 \mu \mathrm{m}$ was assigned to the fraction $>31 \mu \mathrm{m}$. Particle size data of Harrod (1981) showed that, for the Hallsworth soil type, fine sand $(60-200 \mu \mathrm{m})$ represented the greatest proportion of mass within the sand classification. Because this fraction used in this experiment also incorporated silt particles (down to $31 \mu \mathrm{m}$ diameter), it was considered acceptable that the mean particle size should be weighted more towards particles in the smaller size fraction.

5. Number of cells per particle; The number of soil-associated E. coli per ml was divided by the number of particles in $1 \mathrm{ml}$ of sample.

6. Number of cells associated with $1 \mathrm{~mm}^{2}$ of surface area for each size fraction; The number of soil-associated E. coli per ml was divided by the total surface area occupied by that size fraction in $1 \mathrm{ml}$ of sample. 


\section{RESULTS}

The purpose of this study was to assess whether E. coli would associate with soil particles and furthermore, would cells preferentially attach to a particular soil particle size fraction. The total proportion of cells demonstrating an affinity for soil particles $\geq 2 \mu \mathrm{m}$ was $35 \%$ of the initial inoculum. A cumulative increase in the proportion of cells associating with the solid fraction was recorded with the removal of each successively smaller size fraction during the sedimentation stage. Figure 2 (white bars) shows the proportion of $E$. coli retained by the different size fractions for $1 \mathrm{~g}$ of Hallsworth soil series added to water at a 1:10 ratio. A significantly higher $(P \leq 0.001)$ proportion $(65 \%)$ of the cells were found to be in the $\leq 2 \mu \mathrm{m}$ or freely suspended size range, relative to all other size fractions. However, discriminating whether cells were attached to particles $\leq 2 \mu \mathrm{m}$ or freely suspended was not possible. For the $\geq 31 \mu \mathrm{m}, 30-16 \mu \mathrm{m}, 15-4 \mu \mathrm{m}$ and 3-2 $\mu \mathrm{m}$ size fractions the percentage of inoculum cells retained was $2,12,14$ and $7 \%$ respectively. No significant difference existed between the proportion of cells retained by the fractions $30-16,15-4$ or $3-2 \mu \mathrm{m}(P>0.05)$. The proportion of cells retained by the $\geq 31 \mu \mathrm{m}$ fraction was significantly smaller $(P \leq 0.05)$ than the fractions 30-16 $\mu \mathrm{m}$ and $15-4 \mu \mathrm{m}$.

Table 1 summarises the volume, surface area, mass and number of particles associated with each size fraction. The data in Table 1 enabled the theoretical number of cells associating per particle of each size fraction to be calculated and thus the number of cells associated with 1 $\mathrm{mm}^{2}$ of surface area for each size fraction could be derived.

Normalised data, showing the number of cells retained per $\mathrm{mm}^{2}$ of surface area for each size fraction is presented in Figure 2 (black bars) and this highlights that there was a significantly $(P \leq 0.001)$ different number of cells associated with a unit surface area of different size fractions. The $30-16 \mu \mathrm{m}$ fraction was found to support a significantly higher $(P \leq 0.001)$ concentration of cells per unit area than all other size fractions $>2 \mu \mathrm{m}$, including the more abundant 15-4 $\mu \mathrm{m}$ fraction. For soil particles $>2 \mu \mathrm{m}$, E. coli showed at least 3.9 times more 
preference to associate with the $30-16 \mu \mathrm{m}$ than any other fraction. There is a considerable shift in importance of the 30-16 $\mu \mathrm{m}$ fraction when data is normalised for surface area. In addition it was confirmed that a greater $(P \leq 0.05)$ concentration of cells associated with 1 $\mathrm{mm}^{2}$ surface area belonging to the $15-4 \mu \mathrm{m}$ and $\geq 31 \mu \mathrm{m}$ fraction than the $3-2 \mu \mathrm{m}$ size fractions.

\section{DISCUSSION}

The main finding of this study was that while $65 \%$ of E. coli associated with the $<2 \mu \mathrm{m}$ fraction, those cells associating with the $>2 \mu \mathrm{m}$ fraction showed preferential attachment (cells per unit area) to soil particles in the size range 30-16 $\mu \mathrm{m}$. The results of this study also confirm our initial view that previous results had indicated that $E$. coli attached to soil particles, and that these were mobilised by hydrological events. This has significant implications for the interpretation of bacterial attachment to different particles and the hydrological movement of cells in soils of different composition. The nature of association of FIOs and sediment have not been fully characterised (Jamieson et al., 2005) and very few studies have investigated the partition of FIOs to different sedimentary fractions (Kay et al., 2007). Our results suggest that the total proportion of cells with an affinity for soil particles $\geq 2 \mu \mathrm{m}$ was $35 \%$ of the initial inoculum. This complements the finding of Characklis et al. (2005) who found that $20-35 \%$ of E. coli were associated with settleable particles in stormwater, estimated using a centrifugation technique. We do not consider that growth and re-growth of $E$. coli was a significant factor in this study due to the largely sub-optimal temperature and nutrient status required for E. coli replication.

The study identified that, under the reported experimental conditions, in a soil-water solution there was preferential attachment of E. coli to those particles in the size range $30-16 \mu \mathrm{m}$ (normalised black bar data; Figure 2). Gauging the proportion of E. coli that may attach to soil particles of different sizes is an important first step in elucidating the potential efficacy of 
mitigation measures, such as vegetated filter strips, for protecting watercourses from direct wash off of faecal bacteria from pasture (Oliver et al., 2007).

The particle fraction $\leq 2 \mu \mathrm{m}$, which included freely suspended cells, accounted for the majority of the inoculated E. coli population in this study, however attempts to further assess the role of smaller clay particles were inconclusive because it was not known whether the increased association of $E$. coli with particles $\geq 0.5 \mu \mathrm{m}$ to $2 \mu \mathrm{m}$ was a function of increased exposure time during the sedimentation or actual preferential attachment to clay (Oliver, unpublished data). Furthermore, the wider significance of $E$. coli attachment to soil particles of an equal size or smaller than the diameter of an E. coli bacterial cell is unclear in the context of hydrological mobilisation dynamics. It is possible that cells attaching to soil particles of a similar and smaller diameter will be mobilised together with unattached cells in water flux through the soil, and that those cells that can be readily identified as attaching to larger soil particles may be of importance in assessing the likelihood of $E$. coli persistence in soils or vegetated filter strips (Fiener and Auerswald, 2003). Others investigating the transported state of E. coli in overland flow from silt loam plots have suggested that the bacteria were predominantly associated with particles less than $20 \mu \mathrm{m}$ in diameter as opposed to larger soil particles (Muirhead et al., 2006).

Of the bacterial cells attached to soil particles, the greatest proportion of soil-associated $E$. coli was found in the size fraction 15-4 $\mu \mathrm{m}$ (White bars, Fig. 2). Other studies, examining storm flow sediments from rivers, have reported that over $90 \%$ of faecal coliforms are associated with particles in the range of 0.45 to $10 \mu \mathrm{m}$ (Auer and Niehaus, 1993). Schillinger and Gannon (1985) were only able to determine cell association with particles $\geq 5 \mu \mathrm{m}$ in urban stormwater for similar practical reasons as described in the research reported here: they concluded that approximately $16 \%$ of faecal coliforms were associated with particles in excess of $5 \mu \mathrm{m}$. In contrast, Borst and Selvakumar (2003) observed no correlation between faecal coliform or faecal streptococcus concentrations and mean particle size. The few 
previously reported results are highly variable and this may point to the need to evaluate results on a case-by-case basis, with reference to the soil textural make-up where applicable.

Despite cells being more abundant in the $15-4 \mu \mathrm{m}$ fraction, it was the $30-16 \mu \mathrm{m}$ fraction of soil particles that accommodated the highest concentration of cells per unit area. Much of the literature does not present the data in this format, however, Palmateer et al. (1993) did normalise their data and observed that suspended sediments discharged from an agricultural drain in summer tended to be highly colonized with faecal bacteria at a concentration of $6.5 \mathrm{x}$ $10^{5}$ bacteria per $\mathrm{mm}^{2}$ of particulate surface area. Palmateer et al. (1993) observed a significant change in cell numbers per unit surface area in the autumn when particulates in the headwaters of the agricultural drain were colonized with 450 bacteria per $\mathrm{mm}^{2}$ surface area; this is of similar magnitude to the number of $E$. coli associated with two of the size fractions investigated in this study.

Previous research has reported that as much as $99.2 \%$ of $E$. coli can be adsorbed to soil particles $\geq 1 \mu \mathrm{m}$ in a clay loam (Ling et al., 2002). It was suggested that the clay content of the soil strongly affected adsorption of $E$. coli. Clay particles have also been reported as being influential on the adsorption of agricultural contaminants such as, for example, phosphates (Magesan et al., 2003). As the $\leq 2 \mu \mathrm{m}$ fraction could not be investigated in this study, it may be that a significant proportion of cells were associated with the 1-2 $\mu$ m clay fraction of Rowden soil and this would explain the deficit between the results in this study and that of Ling et al. (2002). Alternatively, differences may be attributed to the presence of different types of clay minerals that affect sorption, the soil:solution ratio used, cell exposure time to soil and mixing speed of soil-cell solutions. Differences in attachment of laboratory and environmental isolates to soil particles have also been found. Using a New Zealand silt loam in an experimental static system, $24 \%$ of an introduced laboratory E. coli strain was found to attach to soil particles, compared to $81 \%$ of an environmental strain following 30 minutes contact time between cells and soil (Muirhead et al., 2006). 
In conclusion, turbid runoff is likely to be comprised of a mixture of both freely suspended and particle-associated E. coli. We report that E. coli preferentially associates with different soil particle size fractions in varying proportions. This may allow for a differential hydrological transfer of cells through soil depending on particle size and flow condition and soil type. Implications of forming a cell-particle composite may also impact once E. coli are delivered to vegetated filter strips and surface waters. This is because the significant proportion of $E$. coli that remains unattached or associated with particles $\leq 2 \mu \mathrm{m}$ are likely to (i) avoid the removal mechanism of filter strips and (ii) remain buoyant in the water column and thus able to cause potential contamination problems further downstream. In contrast, the smaller proportion of E. coli associated with larger soil particles are more likely to sediment out into the stream bed and delay possible impairment of water quality upon re-suspension.

\section{ACKNOWLEDGEMENTS}

The authors thank Dan Dhanoa for advice and guidance on statistical matters. This research was funded by a University of Sheffield research studentship. The Institute of Grassland and Environmental Research (IGER) is supported by the Biotechnology and Biological Sciences Research Council (BBSRC).

\section{REFERENCES}

Arriaga, F. J., Lowery, B., \& Mays, M. D. (2006). A fast method for determining soil particle size distribution using a laser instrument. Soil Science, 171, 663-674

Auer, M. T. \& Niehaus, S. L. (1993). Modeling fecal coliform bacteria 1: field and laboratory determination of loss kinetics. Water Reearch, 27, 693-701

Borst, M. \& Selvakumar, A. (2003). Particle-associated microorganisms in stormwater runoff. Water Research, 37, 215-223 
Characklis, G. W., Dilts, M. J., Simmons III, O. D., Likirdopulos, C. A., Krometis, L. A. H., \& Sobsey, M. D., (2005). Microbial partitioning to settleable particles in stormwater. Water Research, 39, 1773-1782

Costerton, J. W., Geesey, G. G., \& Cheng, K. J. (1978). How bacteria stick. Scientific American, 238, 86-95

Fiener, P. \& Auerswald, K. (2003). Effectiveness of grassed waterways in reducing runoff and sediment delivery from agricultural watersheds. Journal of Environmental Quality, $32,927-936$

Gannon, J. T., Mingelgrin, U., Alexander, M., \& Wagenet, R. J. (1991). Bacterial transport through homogeneous soil. Soil Biology and Biochemistry, 23, 1155-1160

Guber, A. K., Shelton, D. R., \& Pachepsky, Y. A. (2005). Effect of manure on Escherichia coli attachment to soil. Journal of Environmental Quality, 34, 2086-2090

Harrod, T. R. 1981. The soils of North Wyke and Rowden. Soil Survey of England and Wales, Grassland Research Institute, Harpenden, UK

Jamieson, R., Joy, D. M., Lee, H., Kostaschuk, R., \& Gordon, R. (2005). Transport and deposition of sediment-associated Escherichia coli in natural streams. Water Research, $39,2665-2675$

Kay, D., Edwards, A. C., Ferrier, R. C., Francis, C., Kay, C., Rushby, L., Watkins, J. McDonald, A. T., Wyer, M., Crowther, J., \& Wilkinson, J. (2007). Catchment microbial dynamics: the emergence of a research agenda. Progress in Physical Geography, 31, $59-76$

Kuczynska, E, Shelton, D. R., \& Pachepsky, Y. (2005). Effect of bovine manure on Cryptosporidium parvum oocyst attachment to soil. Applied and Environmental Microbiology, 71, 6394-6397

Ling, T. Y., Achberger, E. C., Drapcho, C. M., \& Bengtson, R. L. (2002). Quantifying adsorption of an indicator bacteria in a soil-water system. Transactions of the ASAE, 45, $669-674$ 
Lunsdorf, H., Erb, R. W., Abraham, W. R., \& Timmis, K. N. (2000). 'Clay hutches': a novel interaction between bacteria and clay minerals. Environmental Microbiology, 2, 161168

Magesan, G. N., Bolan, N. S., \& Lee, R. (2003). Adsorption of atrazine and phosphate as affected by soil depth in allophanic and non-allophanic soils. New Zealand Journal of Agricultural Research, 46, 155-163

Marshall, K. C. (1975). Clay mineralogy in relation to survival of soil bacteria. Annual Review of Phytopathology, 13, 357-373

McCaulou, D. R., Bales, R. C., \& Arnold, R. G. (1995). Effect of temperature controlled motility on transport of bacteria and microspheres through saturated sediment. Water Resources Research,, 31, 271-280

McGechan, M. B. \& Vinten, A. J. A. (2003). Simulation of transport through soil of E. coli derived from livestock slurry using the MACRO model. Soil Use and Management, 19, $321-330$

Muirhead, R. W., Collins, R. P., and Bremer, P. J. (2006). Interaction of Escherichia coli and soil particles in runoff. Applied and Environmental Microbiology, 72, 3406-3411

Muirhead, R. W., Collins, R. P., and Bremer, P. J. (2006). The association of E. coli and soil particles in overland flow. Water Science and Technology, 54, 153-159

Nagels, J. W., Davies-Colley, R. J., Donnison, A. M., \& Muirhead, R. W. (2002). Faecal contamination over flood events in a pastoral agricultural stream in New Zealand. Water Science and Technology, 45, 45-52

Oliver, D. M. (2005). Hydrological pathways and processes of Escherichia coli transfer from grassland soils to surface waters. PhD thesis. University of Sheffield

Oliver, D. M., Heathwaite, A. L. Haygarth, P. M., \& Clegg, C. D. (2005a). Transfer of Escherichia coli to water from drained and undrained grassland after grazing. Journal of Environmental Quality, 34, 918-925 
Oliver, D. M., Clegg, C. D., Haygarth, P. M., and Heathwaite, A. L. (2005b). Assessing the potential for pathogen transfer from grassland soils to surface waters. Advances in Agronomy, 85, 125-180

Oliver, D. M., Heathwaite, A. L., Hodgson, C. J., and Chadwick, D. R. (2007). Mitigation and current management attempts to limit pathogen survival and movement within farmed grasslands. Advances in Agronomy, 93, 95-152

Palmateer, G., McLean, D. E., Kutas, W. L., \& Meissner, S. M. (1993). Suspended particulate/bacterial interaction in agricultural drains. (In S. S. Rao (ed), Particulate matter and aquatic contaminants (pp. 1-40) CRC Press Inc., Florida)

Schillinger, J. E. \& Gannon, J. J. (1985). Bacterial adsorption and suspended particles in urban stormwater. Journal of theWater Pollution Control Federation, 57, 384-389

Signor, R. S., Roser, D. J., Ashbolt, N. J., and Ball, J. E. (2005). Quantifying the impact of runoff events on microbiological contaminant concentrations entering surface drinking source waters. Journal of Water and Health, 3, 453-468

Strenstrom, T. A. (1989). Bacterial hydrophobicity, an overall parameter for the measurement of adhesion potential to soil particles. Applied and Environmental Microbiology, 55, $142-147$

Tyrell, S. F. \& J. N. Quinton (2003). Overland flow transport of pathogens from agricultural land receiving faecal wastes. Journal of Applied and Environmental Microbiology, 94, 87S-93S

USDA Soil Conservation Service. (1975). Soil taxonomy: a basic system for soil classification for making and interpreting soil surveys. USDA-SCS, New York 


\section{Figure legends:}

Figure 1: The two-step batch sorption experiment

Figure 2: Average proportion of E. coli associated with each particle size fraction for $1 \mathrm{~g}$ of soil (White bars); Escherichia coli associated with $1 \mathrm{~mm}^{2}$ of surface area for each particle size fraction (Black bars) - Note shift in importance of the 16-30 $\mu \mathrm{m}$ fraction when data is normalised for surface area. It is not possible to calculate CFU per $\mathrm{mm}^{2}$ soil fraction for the $<2 \mu \mathrm{m}$ and freely suspended size fraction. Error bars represent 1 S.E.

\section{Table legend:}

Table 1: The volume, surface area, particle density, mass and number of particles associated with each size fraction. Volume of particles were calculated from the radius of the mid point of each size fraction except for $\geq 31 \mu \mathrm{m}$ fraction where $200 \mu \mathrm{m}$ was used as upper limit to weight particles in smaller fractions. Results were determined from the addition of $1 \mathrm{~g}$ of soil to $50 \mathrm{~mL}$ of water. Results are shown per $\mathrm{mL}$ to reflect the $1 \mathrm{~mL}$ pipette sample. particle density of $2.6 \mathrm{~g} \mathrm{~cm}^{3}$ was used for all calculations. values shown are mean values. 


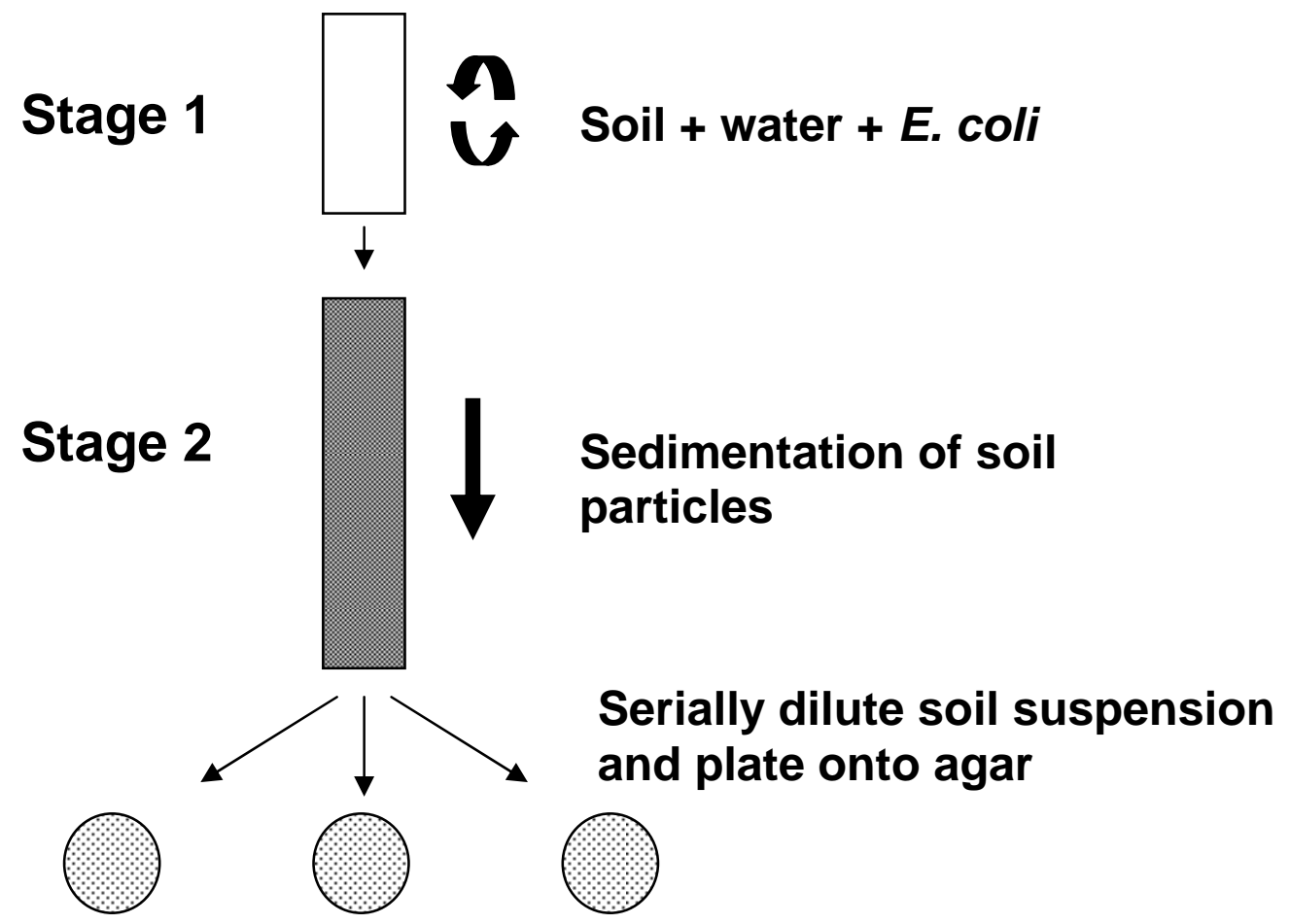

Figure 1: The two-step batch sorption experiment 


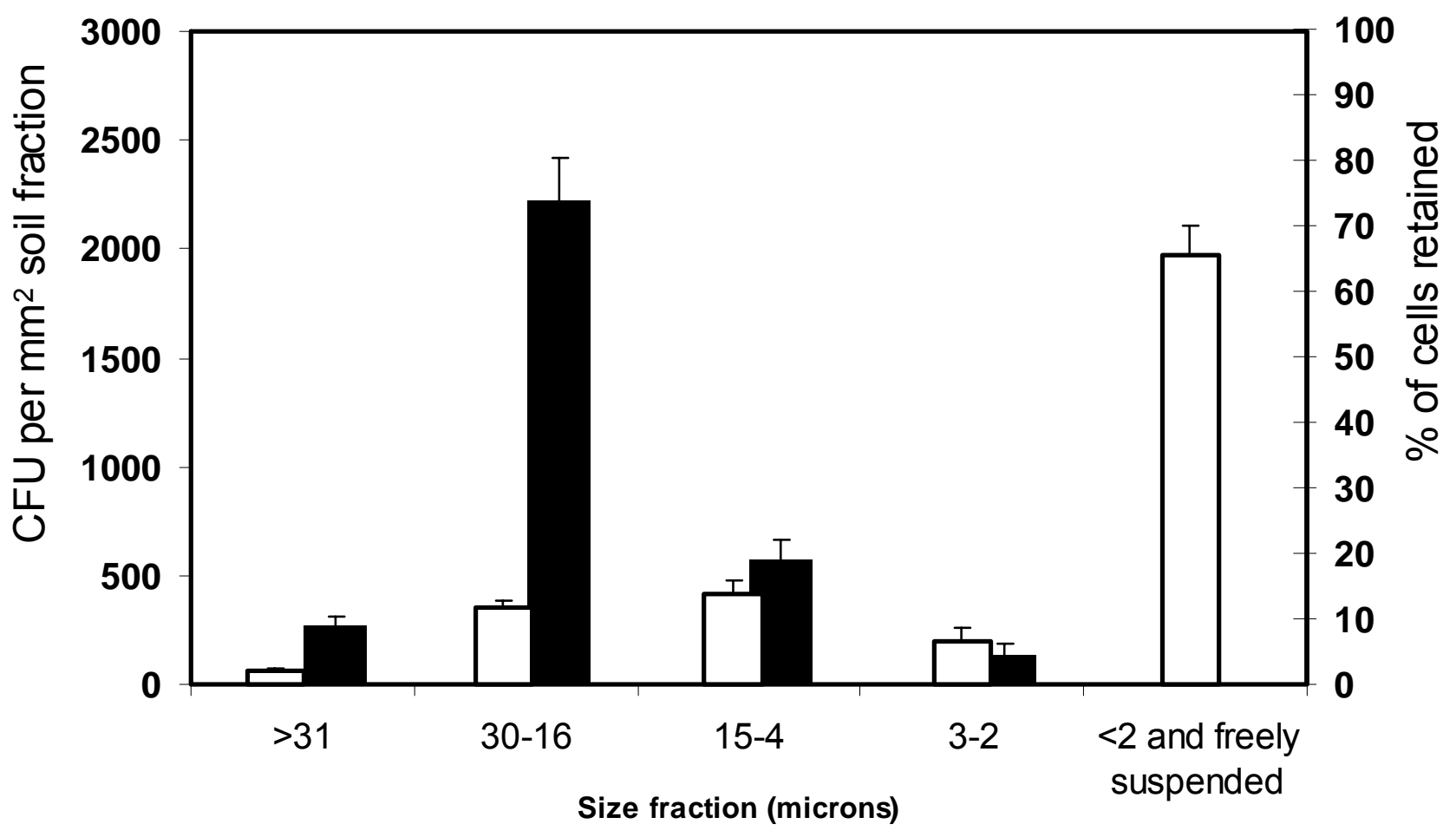

Figure 2: Average proportion of E. coli associated with each particle size fraction for $1 \mathrm{~g}$ of soil (white bars); Escherichia coli associated with $1 \mathrm{~mm}^{2}$ of surface area for each particle size fraction (Black bars) - Note shift in importance of the 16-30 $\mu$ m fraction when data is normalised for surface area. It is not possible to calculate CFU per $\mathrm{mm}^{2}$ soil fraction for the $<2 \mu \mathrm{m}$ and freely suspended size fraction. Error bars represent 1 S.E. 
Table 1: The volume, surface area, particle density, mass and number of particles associated with each size fraction. Volume of particles were calculated from the radius of the mid point of each size fraction except for $\geq 31 \mu \mathrm{m}$ fraction where $200 \mu \mathrm{m}$ was used as upper limit to weight particles in smaller fractions. Results were determined from the addition of $1 \mathrm{~g}$ of soil to $50 \mathrm{~mL}$ of water. Results are shown per $\mathrm{mL}$ to reflect the $1 \mathrm{~mL}$ pipette sample.

\begin{tabular}{|c|c|c|c|c|c|c|c|}
\hline $\begin{array}{l}\text { Size fraction } \\
\text { (equivalent } \\
\text { spherical } \\
\text { diameter) } \\
\text { (microns) }\end{array}$ & $\begin{array}{c}\text { Equivalent } \\
\text { spherical radius } \\
\text { used in } \\
\text { calculations } \\
\text { (microns) }\end{array}$ & $\begin{array}{l}\text { Total mass of } \\
\text { fraction in } 1 \mathrm{~mL} \\
(\mathrm{mg})\end{array}$ & $\begin{array}{c}\% \text { composition } \\
\text { of soil }\end{array}$ & $\begin{array}{l}\text { Volume of } \\
\text { spherical grain } \\
\left(\mathrm{cm}^{3}\right)\end{array}$ & $\begin{array}{l}\text { Number of } \\
\text { particles in } 1 \\
\text { mL sample }\end{array}$ & $\begin{array}{l}\text { Surface area of } \\
1 \text { spherical } \\
\text { grain }\left(\mathbf{m m}^{2}\right)\end{array}$ & $\begin{array}{r}\text { Surface area of } \\
\text { each particle } \\
\text { size fraction in } \\
1 \mathrm{~mL} \text { sample } \\
\left(\mathrm{mm}^{2}\right)\end{array}$ \\
\hline$\geq 31$ & 57.8 & 10.2 & 51.2 & $8.07 \times 10^{-7}$ & $4.88 \times 10^{3}$ & $4.19 \times 10^{-2}$ & $2.05 \times 10^{2}$ \\
\hline $16-30$ & 11.5 & 2.3 & 11.5 & $6.37 \times 10^{-9}$ & $1.38 \times 10^{5}$ & $1.66 \times 10^{-3}$ & $2.30 \times 10^{2}$ \\
\hline $4-15$ & 4.8 & 3.6 & 17.9 & $4.49 \times 10^{-10}$ & $3.07 \times 10^{6}$ & $2.84 \times 10^{-4}$ & $8.72 \times 10^{2}$ \\
\hline $2-3$ & 1.3 & 2.0 & 10.1 & $8.18 \times 10^{-12}$ & $9.51 \times 10^{7}$ & $1.96 \times 10^{-5}$ & $1.87 \times 10^{3}$ \\
\hline
\end{tabular}

particle density of $2.6 \mathrm{~g} \mathrm{~cm}^{3}$ was used for all calculations

values shown are mean values 